\title{
Selectivity of a fishing gear used in the catch of Anomalocardia flexuosa in the Northeast of Brazil
}

\section{Severino Adriano de Oliveira Lima ${ }^{*}$ (iD) Humber Agrelli Andrade ${ }^{2}$ (D) Alfredo Olivera Gálvez ${ }^{2}$ (D)}

${ }^{1}$ Departamento de Pesca e Aquicultura, Universidade Federal de Rondônia (UNIR), 76916.000, Presidente Médici, RO, Brasil. E-mail: limasao@unir.br. "Corresponding author.

${ }^{2}$ Departamento de Pesca e Aquicultura, Universidade Federal Rural de Pernambuco (UFRPE), Recife, PE, Brasil.

ABSTRACT: A type of dredge was introduced as fishing gear along the extractive bank of Mangue Seco-PE from which the largest annual catch of Anomalocardia flexuosa in the world is extracted. This study was carried out with the objective of estimating the selectivity of the new fishing gear and quantitatively evaluating the length classes most compromised by the catches, especially considering 20 mm as the reference value. Specimens larger than this size are most likely to be mature. For the selectivity estimation, the methodology using codends (16 or 20 mm) and small meshed cover $(2 \mathrm{~mm})$ was used. To estimate the selectivity parameters, a logistic regression and the Bayesian approach were used. The transition between the state in which the specimen is invulnerable to the fishing gear and vulnerable occurs between 10 and 18 mm, using a $16 \mathrm{~mm}$ mesh, and using a $20 \mathrm{~mm}$ mesh, this transition is between 14 and $20 \mathrm{~mm}$. Dredgers with $16 \mathrm{~mm}$ and $20 \mathrm{~mm}$ mesh compromise a large proportion of specimens smaller than $20 \mathrm{~mm}$. If the intention is to protect this part of the population, measures such as total restriction of the $16 \mathrm{~mm}$ mesh and use of the $20 \mathrm{~mm}$ mesh should be necessary only in the months of less catching incidences, or increasing the mesh to $25 \mathrm{~mm}$. Key words: coastal ecosystem, mangue seco beach, Benthic macrofauna, Anomalocardia brasiliana, fishing, dredge.

Seletividade de um petrecho de pesca utilizado na captura da Anomalocardia flexuosa no Nordeste do Brasil

RESUMO: Um tipo de draga foi introduzido como arte de pesca no banco extrativista de Mangue Seco - PE de onde se extrai a maior captura anual de Anomalocardia flexuosa do mundo. Este trabalho foi realizado com objetivo de estimar a seletividade do novo petrecho de pesca e avaliar quantitativamente quais são as classes de comprimento mais penalizadas nas capturas, tendo especialmente como referencial o valor de $20 \mathrm{~mm}$. Exemplares maiores que esse tamanho tem elevada probabilidade de estarem maturos. Para estimativa da seletividade foi utilizado o método com uso de saco (16 ou $20 \mathrm{~mm}$ ) e sobresaco $(2 \mathrm{~mm})$. Para estimativa dos parâmetros de seletividade foi utilizada regressão logística e abordagem bayesiana. A transição entre o estado em que o exemplar é invulnerável à arte de pesca e em que o mesmo seria quase com certeza capturado ocorre para malha de $16 \mathrm{~mm}$ entre 10 e $18 \mathrm{~mm}$, enquanto para malha de $20 \mathrm{~mm}$ essa transição se dá entre 14 e $20 \mathrm{~mm}$. As dragas com malha de 16 e 20 mm penalizam uma proporção grande de exemplares menores que 20 mm. Se a intenção é proteger essa parcela da população, seriam necessárias medidas como a restrição total da malha de $16 \mathrm{~mm}$ e uso da malha de $20 \mathrm{~mm}$ somente nos meses de menor incidencia de recrutamento, ou o aumento da malha para $25 \mathrm{~mm}$.

Palavras-chave: ecossistema costeiro, praia de mangue seco, macrofauna bentônica, Anomalocardia brasiliana, pesca, draga.

\section{INTRODUCTION}

Several species of benthic malacofauna are important fishing resources (DEFEO \& CASTILLA, 2005; OLIVEIRA et al., 2017). The Veneridae bivalve Anomalocardia flexuosa has a wide distribution occurring in the Antilles, Brazil and Uruguay (RIOS, 1994). The traditional small-scale fisheries account for nearly all the catches of this bivalve in the world (SILVA-CAVALCANTI \& COSTA, 2011). The Northeastern Region contributes greatly to production, especially the state of Pernambuco, which was already considered as the main producer of the species in Brazil according the available statistics (IBAMA/CEPENE, 2008). In Pernambuco,
A. flexuosa fishing is mainly carried out at the Mangue Seco beach in the municipality of Igarassu, which accounts for approximately $50 \%$ of the state catches (IBAMA/CEPENE, 2008). Along this bank, the activity is developed under a regime of "free access", which often leads to an overexploitation that refers to a scenario typically associated with the "tragedy of the commons" concept (HARDIN, 1968), which results in negative social and ecological consequences.

In order to evaluate the effects of the dredging process, the use of bivalve mollusks can be done manually or with several types of fishing gear (e.g. SILVA-CAVALCANTI et al., 2009). These dredges are widely used, for example, in Portugal (OLIVEIRA et al., 2017), and in Southern 
Brazil, specifically for A. flexuosa (PEZZUTO et al., 2010). In the case of Pernambuco, this activity was predominantly performed by women and children by manual collection (SILVA-CAVALCANTI et al., 2009). However, the number of fishermen has increased considerably over the years, especially with the entry of men into the activity. In addition, a type of dredge known locally as "puçá" has been developed and introduced. No precise information is available on when the dredger with the current configurations began to be used at Mangue Seco beach, but it is known that this capture medium was initially operated by men (OLIVEIRA et al., 2014). Currently, this fishing gear has become popular and has become one of the most used in Mangue Seco, being operated by both men and women.

The introduction of new fishing gear leads to the need for studies on their impact. Estimates of selectivity parameters are especially important for fishing management in cases where minimum size limits for capturing as an alternative management are intended to be used. First catch length, selection factor and selection interval estimates obtained in selectivity studies, are useful for identifying the sizes of individuals retained in fishing operations (NOACK et al., 2017). From selectivity and catch size structure studies, the most severely compromised fishing length classes are identified, and it is possible to use management rules to protect different parts of the population, such as juveniles.

The minimum recommended size for the capture of A. flexuosa for several extractive banks in Brazil is generally $20 \mathrm{~mm}$ shells on the anteroposterior direction (e.g. ARRUDA-SOARES et al., 1982; SILVA-CAVALCANTI \& COSTA, 2011; OLIVEIRA et al., 2014; SANTOS et al., 2014; PEZZUTO et al., 2015). This guideline is based on information that the probability of it being a mature individual is greater than $90 \%$ for those with a length greater than $20 \mathrm{~mm}$ (BARREIRA \& ARAÚJO, 2005).

The dredges currently used in Mangue Seco were introduced without a preliminary study on selectivity and captured sizes. In addition, the fishing scenario is not controlled and develops in the direction of maximizing profit in the moment, without considerations on future perspectives that can be negative. Therefore, in this study the objective was to estimate the selectivity of the dredge recently introduced in Mangue Seco, in order to quantitatively evaluate which are the classes of length most compromised in the catches. These results are useful for making management decisions, aiming to maintain a profitable and sustainable activity.

\section{MATERIALS AND METHODS}

\section{Study area}

The extractive bank of Mangue Seco beach is located in the state of Pernambuco ( $7^{\circ} 49^{\prime} 48^{\prime \prime} \mathrm{S}$ and $\left.34^{\circ} 50^{\prime} 24^{\prime \prime} \mathrm{W}\right)$. The area of the Mangue Seco bank is approximately $2.9 \mathrm{~km}^{2}$ and is exposed to the marine environment, but it is also influenced by the river tributaries of the Timbó river in the Southern limit, and the Santa Cruz Canal in the Northern limit. The beach line is two kilometers long, going from southnorth along the coast, with shallow waters and small waves (OLIVEIRA et al., 2014).

\section{Description of fishing gear and data collection}

The dredger consists of an approximately $2 \mathrm{~m}$ wooden rod inserted in a generally triangular (or round) stainless steel support, with or without teeth in the inferior border. Threaded to the support is a mesh codend of 16 or $20 \mathrm{~mm}$ between opposing stretched knots (osk) in most cases (Figure 1 A). To operate the device, the fishermen use a cable attached between the wooden rod and their waist, facilitating the execution of the drag of the artifact in the sediment. In commercial dragging, the distances traveled are short ( 5 to $10 \mathrm{~m}$ ) to prevent clogging, facilitating washing, sediment flow and the escape of small individuals.

In the experiments, the 16 or $20 \mathrm{~mm}$ (osk) tongs were wrapped with $2 \mathrm{~mm}$ square meshes (osk) called "small meshed cover" (Figure 1 B). These tongs with codend and small meshed cover were dragged by a local fisherman in a procedure similar to that used in the commercial fishery. In total, four experiments were carried out, two with a $16 \mathrm{~mm}$ mesh dredger, one in December 2016 and one in June 2017, and two with a $20 \mathrm{~mm}$ mesh dredger in the same periods that were selected to contemplate all the size classes, and thus minimizing the effects of seasonality, as there is a higher frequency of adult individuals in the rainy season (OLIVEIRA et al., 2014). In the experiments a dredger model was used having a triangular shape with teeth (Figure 1A).

From the captures observed in the codend and in the small meshed cover, it is possible to estimate the proportions of specimens retained in the codend and those that escaped for different length classes. The ratio retained in the codend for each i-th class of length is: $\mathrm{P}_{\mathrm{i}}=\mathrm{C}_{\mathrm{si}} /\left(\mathrm{C}_{\mathrm{si}}+\mathrm{C}_{\mathrm{ssi}}\right), \quad$ (1) if $\mathrm{C}_{\mathrm{si}}$ and $\mathrm{C}_{\mathrm{ssi}}$ are the amounts retained in the codends and small meshed cover, respectively. For the analysis, all the specimens collected in the codend and the cover- codend were packed in plastic codends and taken to the laboratory. There the lengths between the ends were measured 

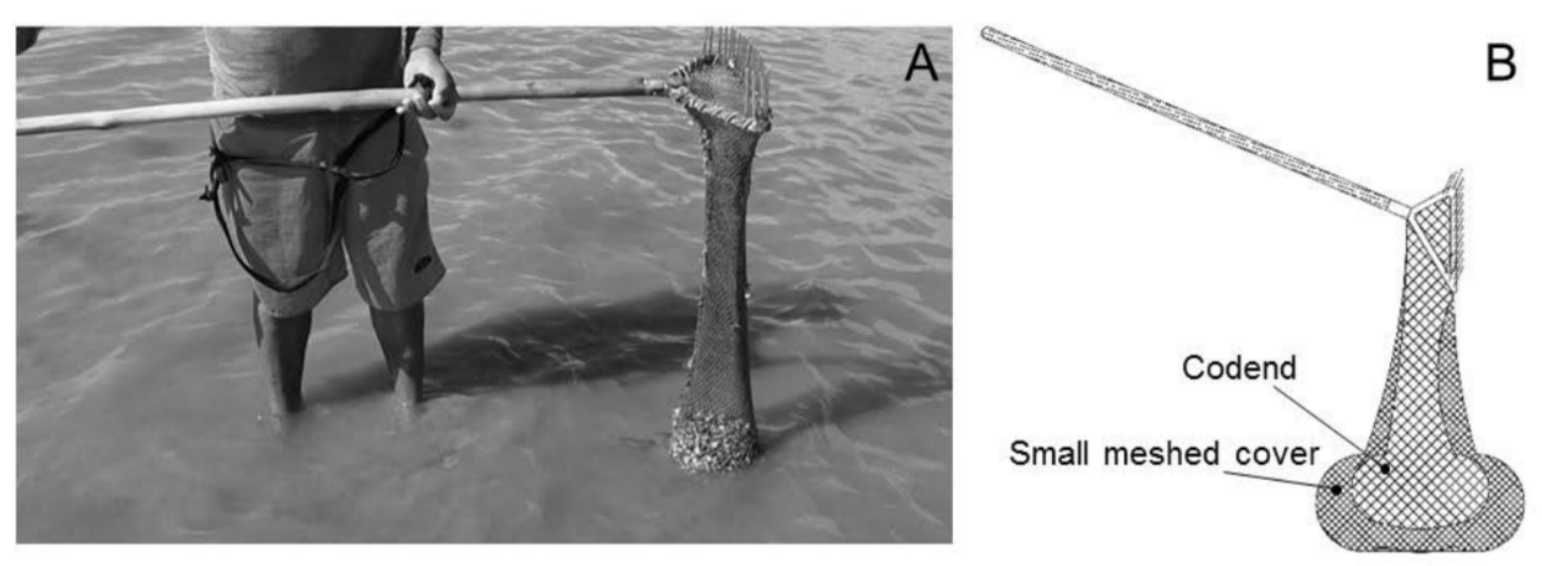

Figure 1 - Dredge used for extraction of Anomalocardia flexuosa at Mangue Seco beach (A), and schematic drawing of the artifact used in the experiment (B) - No scale.

in the anteroposterior direction of the shell, with a manual precision pachymeter of $0.02 \mathrm{~mm}$.

\section{Data analyses}

A chi-square test was used to compare the proportions of individuals with an anteroposterior shell length greater than $20 \mathrm{~mm}$ retained in drags performed with $16 \mathrm{~mm}$ and $20 \mathrm{~mm}$ dredges. For the estimation of the selectivity parameters, logistic regression was used with a generalized linear model and the Bayesian approach. Logistic regression can be applied to evaluate dichotomous variables. In our case, each specimen of $A$. flexuosa can be retained (success) or not retained (failure) in the codend. The number of copies of the $i$-th class of length retained in the codend $\mathrm{y}_{\mathrm{i}}$ was considered as a binomial variable $\mathrm{y}_{\mathrm{i}}$ $\sim \operatorname{Bin}\left(n_{i}, \theta_{i}\right)$, where $n_{i}$ is the total number of specimens (codend + cover- codend), and $\theta_{i}$ is the probability of retention of the $i$-th class in the codend.

It is convenient to treat $\theta_{\mathrm{i}}$ on a transformed scale, since it is restricted to space [0.1]. For this, one can use in the context of a generalized linear $n_{i}=g\left(\theta_{i}\right)$ $=\log \left(\theta_{\mathrm{i}} /\left(1-\theta_{\mathrm{i}}\right)\right.$, where $\mathrm{n}_{\mathrm{i}}$ is the linear predictor, and $\mathrm{g}()$ the logit connection function. The linear predictor is a function of the length in the form $n_{i}=\beta_{0}+\beta_{1} x_{i}$, where $\beta_{0}$ and $\beta_{1}$ are parameters yet to be established, and $x_{i}$ is the average point of the $i$-th class of length.

In the Bayesian approach, the joint posterior distribution of the parameters conditioned to the available information is computed for $\mathrm{p}\left(\beta_{0}, \beta_{1} \mid\right.$ data $)=\mathrm{p}\left(\beta_{0}, \beta_{1}\right) / \mathrm{p}\left(\right.$ data $\left.\mid \beta_{0}, \beta_{1}\right) \mathrm{p}($ data $)(2)$, where $\mathrm{p}\left(\beta_{1}, \beta_{2}\right)$ is the priori distribution for the parameters, $\mathrm{p}\left(\right.$ data $\left.\mid \beta_{0}, \beta_{1}\right)$ is the likelihood function and $\mathrm{p}($ data $)$ $=\int \mathrm{p}\left(\beta_{0}, \beta_{1}\right) \mathrm{p}\left(\right.$ data $\left.\mid \beta_{0}, \beta_{1}\right)$ (3) it is a normalization constant. The data correspond to the $\mathrm{y}, \mathrm{n}$ and $\mathrm{x}$ values of the different length classes. The likelihood function is binomial, and for the priori distributions of the two parameters we used normal distributions with mean of 0 with a standard deviation of 100 ; which are therefore, not informative. A sample of the joint posterior distribution $\mathrm{p}\left(\beta_{0}, \beta_{1} \mid\right.$ data $)$ was obtained using a Monte Carlo algorithm with Markov Chains and Gibbs sampler with the aid of the JAGS (PLUMMER, 2017) and R (R CORE TEAM, 2018) programs, and the runjags package (DENWOOD, 2016). Three chains were started with different values for the parameters. The first 50,000 values were discarded (burnin), and thereafter values were retained every 50 of the subsequent 50,000 steps of each chain. As a result, 1000 values of the posterior distribution were obtained for each of the three chains, totaling a sample of 3,000 values.

In the convergence diagnosis of the chains and to verify if the stationarity was reached, we used dash plots and the Potential Scale Reduction Factor (PSRF) by GELMAN \& RUBIN (1992). Convergence was considered to be achieved when the $97.5 \%$ quartile of PSRF was less than 1.01. Calculations for convergence and stationarity diagnoses were performed using the CODA package (PLUMMER et al., 2006) of the R program.

Based on the estimates of the subsequent joint distribution of $\beta_{0}$ and $\beta_{1}$, the lengths for which $25 \%$ (L25), $50 \%$ (L50) and 75\% (L75) of the individuals are expected to be retained, the Selection Interval (SI = L75 - L25) (4), and the Selection 
Factor $(\mathrm{SF}=\mathrm{L} 50 / \mathrm{m})(5)$, where $\mathrm{m}$ is the mesh length (SPARRE \& VENEMA 1988) were calculated.

\section{RESULTS AND DISCUSSION}

In total, together with the samples of the codend and the small meshed cover, 2955 were captured in the $16 \mathrm{~mm}$ mesh experiments and 2879 in the $20 \mathrm{~mm}$ mesh experiments. The percentage of individuals larger than $20 \mathrm{~mm}$ in relation to the total was significantly different in $16 \mathrm{~mm}$ and $20 \mathrm{~mm}$ mesh codend $\left(\mathrm{p}=3.77 \times 10^{-13}\right)$, with a larger proportion in the $20 \mathrm{~mm}$ codend. In the small meshed cover, specimens larger than $20 \mathrm{~mm}$ were not retained.

The maximum likelihood estimates for the parameters $\beta_{0}$ and $\beta_{1},-16.77,1.23$ where in the 16 mm mesh experiments and $-3.67,0.01$ in the $20 \mathrm{~mm}$ mesh experiments. The hypothesis tests indicate that there is evidence to reject the null hypothesis (equal to zero) for three of the four estimated parameters, exception was $\beta_{1}$ in the $20 \mathrm{~mm}$ mesh.

The frequency distributions of the specimens captured in the codend (empty bars) and in the small meshed cover (bars filled in grey) are shown in Figure 2. In general, the largest aggregated catches were between $12 \mathrm{~mm}$ and $20 \mathrm{~mm}$.

The aggregate length frequency distributions (codend + small meshed cover) reflect a less biased size structure of the population in the Mangue Seco bank. However, the length frequency distributions of the catches obtained only in the

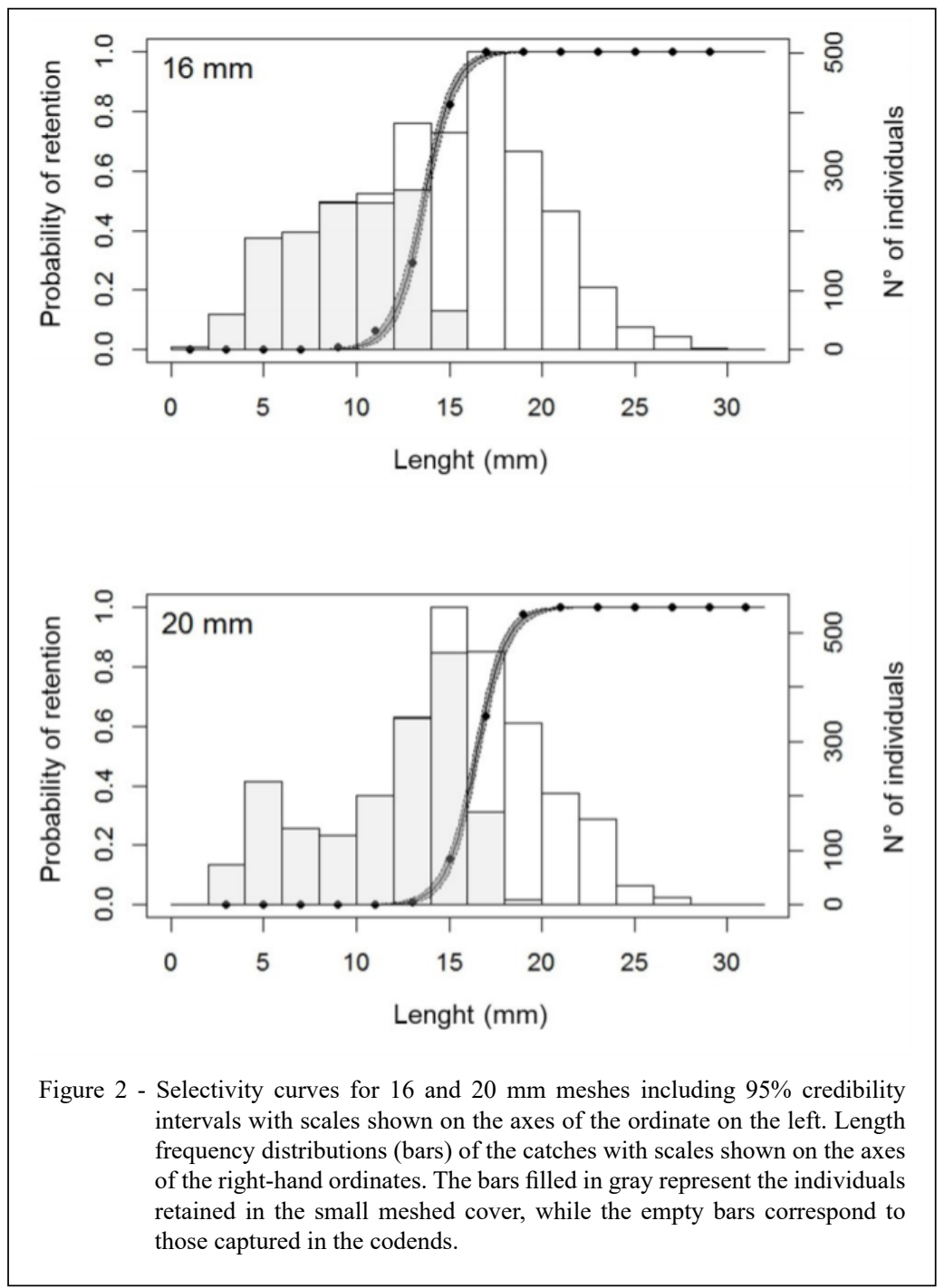

Ciência Rural, v.50, n.8, 2020. 
codends (empty bars - Figure 2) correspond to the most compromised sizes in the fishing events. The lengths between 14 and $22 \mathrm{~mm}$ are the ones most compromised in fishing with a $16 \mathrm{~mm}$ codend, while lengths between $16 \mathrm{~mm}$ and $24 \mathrm{~mm}$ are the most caught in fisheries with a $20 \mathrm{~mm}$ mesh codend.

The proportions retained in the experiments for each length class and adjusted selectivity models for dredges with $16 \mathrm{~mm}$ and $20 \mathrm{~mm}$ meshing in the codends are also shown in Figure 2. The models had a good fit. The estimates obtained indicate that the transition between the state in which the specimen is invulnerable to the fishing gear (selectivity close to zero) and vulnerable if there is contact (selectivity close to one) occurs between 10 and $18 \mathrm{~mm}$ for the $16 \mathrm{~mm}$ mesh, and between 14 and $20 \mathrm{~mm}$ for the $20 \mathrm{~mm}$ mesh.

The estimates of the means of the posterior distributions of L25, L50 and L75 were 12.75, 13.64 and $14.53 \mathrm{~mm}$ respectively for the experiment with 16 $\mathrm{mm}$ mesh, and 15.43, 16.46 and 17.35 , respectively, for the $20 \mathrm{~mm}$ mesh.Conversely, the means of the posterior distributions of the Selection Factor (SF) and the Selection Interval (SI) were 0.85 and 1.78 for the $16 \mathrm{~mm}$ mesh, respectively, and 0.82 and 1.77 for $20 \mathrm{~mm}$ mesh, respectively.

The selectivity curves of the two meshes are generally distinct, with a great difference in lengths that characterize the transition from the invulnerable state ( $\sim 0 \%$ retention) to the vulnerable ( $\sim 100 \%$ retention). However, in both meshes the catches of specimens larger than $20 \mathrm{~mm}$ were less than $40 \%$. Moreover, estimates of first catch (L50) or even L75 sizes are less than $20 \mathrm{~mm}$ for both $(16 \mathrm{~mm}$ or $20 \mathrm{~mm}$ ) meshes.

In the extraction of $A$. flexuosa in Mangue Seco, more conservative measures such as prohibiting the use of the dredge with the meshes evaluated in this study should be considered, since even the larger mesh size $(20 \mathrm{~mm})$ evaluated had a low catch percentage of individuals greater than $20 \mathrm{~mm}$. In this same site it has also been observed that even in operations with manual collection there are relatively low percentages of these individuals above $20 \mathrm{~mm}$ (OLIVEIRA et al., 2014). This implies that the activity has already been developed with increased catches of small individuals for some time, even before the introduction of dredgers. In places where the capture of bivalves with dredges has been used for decades, as in many European countries, fishing is regulated with selectivity-related strategies to preserve juveniles. One of the references used is a shell size of $25 \mathrm{~mm}$ for various bivalve species, including the Veneridae Family (SCARCELLA \&
CABANELAS, 2016). In addition to the minimum catch size, the authors cited above describe several other management alternatives such as the reduction of the number of licenses and the limitation of catch areas to minimize impacts from fishing.

In referring the ideal mesh length for capturing individuals larger than $20 \mathrm{~mm}$, the Selection Factor is a parameter that can be used (SPARRE \& VENEMA, 1988). With the Selection Factor values calculated in this study it is estimated that the mesh sizes should be 24 to $25 \mathrm{~mm}$ so that the first catch length is approximately $20 \mathrm{~mm}$. The increase in mesh size in dredge fishing of bivalves has been suggested recently in bivalve fisheries at other sites in order to preserve young individuals (e.g. GASPAR et al., 2003); but as a consequence, mesh growth can lead to a decrease of the quantities caught. Therefore, it would be important to carry out experiments not only for Mangue Seco, but also for other extraction sites. Thus, estimating the mid- or long-term balance between profitability (captured quantities) and ecology (preserved amounts and proportions of individuals smaller than $20 \mathrm{~mm}$ ), to evaluate the potential of a mesh increase as a management measure. A regulatory measure is more likely to be effectively enforced if there is not a great economic and social burden on the agents involved, because if there is a fall in profitability, the prohibition of meshes would certainly face great resistance from local fishermen.

An alternative that has the possibility of generating less friction would be to allow the use of the already widespread mesh of $20 \mathrm{~mm}$ in the period in which the number of catches is smaller. Despite occurring throughout the year, catches are more significant during some months, and this periodicity can also vary according to the location (BOEHS et al., 2008; RODRIGUES et al., 2013). On the Mangue Seco beach there is no definition about the recruitment peak of $A$. flexuosa; however, there is information for Rio Grande do Norte, a state also located in the northeast region of Brazil and with similar climatic conditions to the studied site. According to RODRIGUES et al. (2013) in an estuarine region of Rio Grande do Norte, the recruitment peak occurred in the first three months of the year (January, February and March) and in the last three (October, November and December). Considering that the same pattern occurs for Mangue Seco, a mesh of approximately $25 \mathrm{~mm}$ is suggested for months of possibly greater catches. The mesh rotation strategy per season can, in some cases, contributed not only to protecting parts of the population (e.g. those smaller than $20 \mathrm{~mm}$ ) 
but also to optimize fishing yield, reducing waste and improving the long-term prospects of the stock (FERRO et al., 2008).

The use of dredge-type fishing gear also requires careful consideration of the possible physical impacts of dredge fishing gear even on individuals that escaped, whether smaller specimens of the target species or even other benthic species. Damage caused by fishing gear may contribute to subsequent mortality of mollusks (MEYER et al., 1981). Even for a robust shell species such as A. flexuosa, a part of the escaped individuals may not survive burial or exposure to epibenthonic predators, so the effect of fishing becomes even more severe (PEZZUTO et al., 2010). The physical impact of fishing on benthic ecosystems is an issue that has been the subject of public attention (EIGAARD et al., 2015).

The level of extraction and adaptation of the extractive activity in Mangue Seco is uncertain. The absence of regulations in Mangue Seco, together with the expansion of the fishing effort, the capture of relatively high proportions of individuals smaller than $20 \mathrm{~mm}$, and the possibility of impacting specimens that are not retained in the dredger's meshes, potentiates a negative scenario for the future. The need for regulations of mollusk fishing with dredgers is important, as is seen in several European countries (SCARCELLA \& CABANELAS, 2016) or even in the Pirajubaé Marine Extractive Reserve in Southern Brazil (PEZZUTO et al., 2015). There, a number of management measures have already been adopted in these areas (e.g. minimum catch size, space-time rotation of fishing areas). Therefore, the extraction activity in Mangue Seco, which is of great regional importance and is the largest in the world for A. flexuosa, demands urgent attention from the institutions responsible for fishing management in Brazil.

Dredgers with 16 and $20 \mathrm{~mm}$ meshing compromise a large proportion of specimens smaller than $20 \mathrm{~mm}$. The restriction of these meshes is an alternative management practice to protect this part of the population, but a less conflicting alternative would be the use of mesh rotation with a total restriction of the $16 \mathrm{~mm}$ mesh and only the use of the $20 \mathrm{~mm}$ mesh in the months for catching less juveniles, and the increase of the mesh to $25 \mathrm{~mm}$ in the months of greater wave of catches. There is a great demand for information on the economic viability of the mesh increase, and on the survival of specimens that escape and are not retained in them. These issues are crucial for the definition of a management policy for the extractive bank of Mangue Seco, which may be the main fishing spot of $A$. flexuosa in the world.

\section{ACKNOWLEDGEMENTS}

The authors would like to thank to the fishermen of the municipality of Mangue Seco for the collaboration in the samplings of the present study and Coordenação de Aperfeiçoamento de Pessoal de Nível Superior (CAPES, Brasil) for the granting of doctoral scholarship.

\section{DECLARATION OF CONFLICT OF INTERESTS}

The authors declare no conflict of interest. The founding sponsors had no role in the design of the study; in the collection, analyses, or interpretation of data; in the writing of the manuscript, and in the decision to publish the results.

\section{AUTHORS' CONTRIBUTIONS}

All authors contributed equally for the conception and writing of the manuscript. All authors critically revised the manuscript and approved the final version.

\section{REFERENCES}

ARRUDA-SOARES, H. et al. Berbigão Anomalocardia brasiliana (Gmelin, 1791) edible bivalve of the Island Region in São Paulo State, Brazil: information Cardoso of concern for commercial fishery. Boletim do Instituto de Pesca, v.9, n1, p.21-38, 1982. Available from: <https://www.pesca.sp.gov.br/boletim/index.php/ bip/article/view/62>. Accessed: May, 11, 2020.

BARREIRA, C.A.R.; ARAÚJO, M.L.R. Reproductive cycle of Anomalocardia brasiliana (Gmelin, 1791) (Mollusca, Bivalvia, Veneridae) at Canto da Barra Beach, Fortim, Ceará, Brazil. Boletim do Instituto de Pesca, v.31, n.1, p.9-20, 2005. Available from: < https://www.pesca.sp.gov.br/boletim/index.php/bip/article/ view/Barreira31 1>. Accessed: May, 11, 2020.

BOEHS, G. et al. Population ecology of Anomalocardia brasiliana (Gmelin, 1791) (Bivalvia, Veneridae) on Paranaguá Bay, Paraná, Brazil. Boletim do Instituto de Pesca, v.34, n.2, p.259-270, 2008. Available from: <https://www.pesca.sp.gov.br/boletim/index.php/ bip/article/view/793>. Accessed: May, 11, 2020.

DEFEO, O.; CASTILLA, J.C. More than one bag for the world fishery crisis and keys for co-management successes in selected artisanal Latin American shellfisheries. Reviews in Fish Biology and Fisheries, v.15, n.3, p.265-283, 2005. Available from: $<$ https:// link.springer.com/article/10.1007\%2Fs 11160-005-4865-0>. Accessed: May, 12, 2020. doi: 10.1007/s11160-005-4865-0.

DENWOOD, M.J. runjags: Run Bayesian MCMC Models in the BUGS syntax from within $\mathbf{R}$-manual. 2016. $<$ http://cran.rproject.org/web/packages/runjags/>. Accessed: Mar. 28, 2018.

EIGAARD, O.R. et al. Estimating seabed pressure from demersal trawls, seines, and dredges based on gear design and dimensions. ICES Journal of Marine Science, v.73, n.1, p.27-43, 2015. Available from: $<$ https://academic.oup.com/icesjms/article/73/suppl_1/i27/2573989>. Accessed: May, 12, 2020. doi: 10.1093/icesjms/fsv099.

FERRO, R.S.T. et al. The potential for optimizing yield from a haddock trawl fishery using seasonal changes in selectivity, 
population structure and fish condition. Fisheries Researsh, v.94, n.2, p.151-159, 2008. doi: 10.1016/j.fishres.2008.08.018. Available from: <https://www.sciencedirect.com/science/article/ abs/pii/S0165783608002683>. Accessed: May, 12, 2020.

GASPAR, M.B. et al. Size selectivity of the Spisula solida dredge in relation to tooth spacing and mesh size. Fisheries Research, v.60, n.2. p.561-568, 2003. doi: 10.1016/S0165-7836(02)001406. Available from: $<\mathrm{https} / /$ www.sciencedirect.com/science/article/ abs/pii/S0165783602001406>. Accessed: May, 12, 2020.

GELMAN, A.; RUBIN, D.B. A single series from the Gibbs sampler provides a false sense of security. In: Bernardo, J.M.; Berger, J.O.; Dawid, A.P.; Smith, A.F.M. Bayesian Statistics. Oxford: Oxford University Press, 1992. p. 625-631.

HARDIN, G. The Tragedy of the Commons. Science, v.162, n.3859, p.1243-1248, 1968. doi: 10.1126/science.162.3859.1243. Available from: <https://science.sciencemag.org/content/162/3859/1243>. Accessed: May, 12, 2020.

IBAMA/CEPENE. Boletim estatístico da pesca marítima estuarina do nordeste do Brasil - 2006. Tamandaré, 2008. 385p.

MEYER, T.L. et al. The performance and environmental effects of a hydraulic clam dredge. Marine Fisheries Review, v.43, n.9, p.14-22, 1981. Available from: <https://spo.nmfs.noaa.gov/ content/performance-and-environmental-effects-hydraulic-clamdredge >. Accessed: May, 12, 2020.

NOACK, T. et al. Codend selectivity in a commercial Danish anchor seine. Fisheries Research, v.186, n.1, p.283-291, 2017. doi: 10.1016/j.fishres.2016.10.006. Available from: <https://www. sciencedirect.com/science/article/abs/pii/S0165783616303344>. Accessed: May, 12, 2020.

OLIVEIRA, I.B. et al. Effect of the rainy season on the extraction of bivalve mollusc Anomalocardia brasiliana (Gmelin, 1791). Revista Brasileira de Ciências Agrárias, v.9, n.1, p.139-145, 2014. Available from: <http://www.agraria.pro.br/ojs-2.4.6/index. php?journal $=$ agraria\&page $=$ article $\&$ op $=$ view $\&$ path $\% 5 \mathrm{~B} \% 5 \mathrm{D}=\mathrm{ag}$ aria_v9i1a2947>. Accessed: May, 12, 2020. doi: 10.5039/agraria. v9i1a2947.

OLIVEIRA, M.M. et al. Forecasting bivalve landings with multiple regression and data mining techniques: The case of the Portuguese Artisanal Dredge Fleet. Marine Policy, v.84, n.10, p,110-118, 2017. Available from: <https://www.sciencedirect.com/science/ article/pii/S0308597X17303159>. Accessed: May, 12, 2020. doi: 10.1016/j.marpol.2017.07.013.

PEZZUTO, P.R. et al. Efficiency and selectivity of the Anomalocardia brasiliana (Mollusca: Veneridae) hand dredge used in southern Brazil. Journal of the Marine Biological Association of the United Kingdom, v.90, n.7, p.1455-1464, 2010. Available from: <https://www.cambridge.org/core/journals/ journal-of-the-marine-biological-association-of-the-unitedkingdom/article/efficiency-and-selectivity-of-the-anomalocardiabrasiliana-mollusca-veneridae-hand-dredge-used-in-southern-bra zil/48C231886F7441D4C8612545BD2913A7>. Accessed: May, 12, 2020. doi: /10.1017/S0025315410000317.
PEZZUTO, P.R.; SOUZA, D.S. Fishing and Management of the Clam (Anomalocardia brasiliana) (Bivalvia: Veneridae) in the Pirajubaé Marine Extractive Reserve, SC, Brazil. Desenvolvimento Meio Ambiente, v.34, n.2, p.169-189, 2015. doi: 10.5380/dma. v34i0.39758. Available from: <https://revistas.ufpr.br/made/ article/view/39758>. Accessed: May, 12, 2020.

PLUMMER, M. JAGS: Just Another Gibbs Sampler. 2017. Available from: <http://mcmc-jags.sourceforge.net/>. Accessed: Mar. 28, 2018.

PLUMMER, M. et al. CODA: Convergence diagnosis and output analysisfor MCMC. R News, v.6, n.1, p.7-11, 2006. Available from: <http://oro.open.ac.uk/22547/>. Accessed: May, 12, 2020.

R CORE TEAM. R: A Language and Environment for Statistical Computing. 2018. <https://www.R-project.org/>. Accessed: Mar. 28,2018 .

RIOS, E.C. Seashells of Brazil. 2. ed. Rio Grande: Fundação da Universidade do Rio Grande 1994. 492p.

RODRIGUES, A.M.L. et al. Population structure of the bivalve Anomalocardia brasiliana, (Gmelin, 1791) in the semi-arid estuarine region of northeastern Brazil. Brazilian Journal of Biology, v.73, n.4, p.819-833, 2013. Available from: $<$ https://www.scielo.br/scielo.php?script=sci_arttext\&pid $=$ S1519-69842013000400819>. Accessed: May, 12, 2020. doi: 10.1590/S1519-69842013000400019.

SANTOS, J.J.S. et al. Population Dynamic of Anomalocardia brasiliana (Mollusca, Bivalvia, Veneridae) in the Estuary of River Paciência in Raposa, Maranhão State. Anuário do Instituto de Geociências, v.37, n.1, p.61-69, 2014. Available from: <http:// www.ppegeo.igc.usp.br/index.php/anigeo/article/view/5990>. Accessed: May, 12, 2020. doi: 10.11137/2014_1_61_69.

SCARCELlA, G.; CABANELAS, A.M. The clam fisheries sector in the EU - The Adriatic Sea case. Directorate-General for Internal Policies of the Union (European Parliament) 2016. 66p.

SILVA-CAVALCANTI, J.S.; COSTA, M. Fisheries in Protected and Non-Protected areas: What is the difference? The case of Anomalocardia brasiliana (Gmelin, 1971) (Mollusca: Bivalvia) at tropical estuaries of Northeast Brazil. Journal of Coastal Research, v.56, p.1454-1458, 2009. Available from: <http:// www.cerf-jcr.org/index.php/international-coastal-symposium/ ics-2009portugal/1460-fisheries-in-protected-and-non-protectedareas-is-it-different-the-case-of-anomalocardia-brasiliana-attropical-estuaries-of-northeast-brazil-js-silva-cavalcanti-and-mfcosta >. Accessed: May, 12, 2020.

SILVA-CAVALCANTI, J.S.; COSTA, M.F. Fisheries of Anomalocardia brasiliana in Tropical Estuaries. Pan-American Journal of Aquatic Sciences, v.6, n.2, p.86-99, 2011. Available from: <https://panamjas.org/artigos.php?id_publi=188>. Accessed: May, 12, 2020.

SPARRE, P.; VENEMA, S.C. Introduction to tropical fish stock assessment.1998. 407 p. (Fisheries Technical Paper Part 1. Manual). 